\title{
Dinamic of Bacteria Desnitrificants and Nitrificants in the Rizospheric of Wheat with Slow Release of Fertilizer, Irrigated with Waste or Well Water
}

\author{
Sandra Grisell Mora-Ravelo ${ }^{1 *}$, Francisco Gavi Reyes ${ }^{2}$, Jesús Pérez Moreno ${ }^{3}$, \\ Juan José Peña Cabriales ${ }^{2}$, Leonardo Tijerina Chávez ${ }^{4}$, Ma. de Lourdes de la Isla de Bauer ${ }^{2}$ \\ ${ }^{1}$ Posgrado en Biología, Instituto Tecnológico de Ciudad Victoria, Ciudad Victoria, México \\ ${ }^{2}$ Programa de Hidrociencias, Colegio de Posgraduados, Montecillo, México \\ ${ }^{3}$ Programa de Edafología, Colegio de Posgraduados, Montecillo, México \\ ${ }^{4}$ Departamento de Biotecnología, CINVESTAV, Irapuato, México \\ Email: "sgmora@colpos.mx
}

Received May 30, 2013; revised June 30, 2013; accepted July 10, 2013

Copyright (C) 2013 Sandra Grisell Mora-Ravelo et al. This is an open access article distributed under the Creative Commons Attribution License, which permits unrestricted use, distribution, and reproduction in any medium, provided the original work is properly cited.

\begin{abstract}
The study of the paper about the rhizosphere in the transformation of nitrogen compounds can generate knowledge of the microbial and biochemical atmosphere of the rhizosphere of wheat, for the understanding of the dynamics of the $\mathrm{N}$ in agricultural zones, with the purpose of optimizing the fertilizer use and increasing the productivity of the cultures. Therefore, the objective of the present work was to know the effect the rhizosphere in the dynamics of the bacterial populations that take part in the cycle of the $\mathrm{N}$ in wheat nourished with slow release fertilizer and one commercial, irrigated with waste water or well. Analyses in the soil took place vertisol used in the experiment with the rhizospheric and non rhizospheric fraction. The slow release fertilizer used has a matrix enriched with $\mathrm{N}$ and $\mathrm{P}$ and is in the process of being patented (it explains in materials and methods). Each fertilizer was evaluated and the combination of the slow release fertilizer with organic fertilizer. The technique of the number most probable was used (MNP) to carry out the quantification of the nitrificants and denitrificants bacteria to the 55, 67 and 97 days after sowing (Dds). The results obtained for the MNP of denitrificants bacteria and Nitrosomonas indicate that the effect average of the types of water, soil and fertilizers, as well as their interaction to each other was not significant $(p>0.05)$. The effect of the fertilizing type and soil (rhizospheric and non rhizospheric) in the MNP of Nitrobacter was significant $(p<0.05)$. The tendencies show that the non rhizospheric soil is more favorable for the development of denitrificants bacteria and Nitrobacter, whereas the MNP of Nitrosomonas was greater in rhizospheric soil.
\end{abstract}

Keywords: Nitrificants; Vermicompost; Nitrites; Nitrates; Ammonium

\section{Introduction}

The rhizosphere constitutes the surface and the immediate region the root surrounds, that provides with an ecological niche to the microorganisms of the soil since in her the nutriments are more available. The atmosphere rhizospheric is a scene integrated by the interaction soil, plants and organisms. Between these the bacteria and fungi are in greater density in the rhizosphere than that in the soil without roots [1]. The interactions between the microorganisms and the roots determine the rhizosphere effect, on same populations and the activity of the mi-

${ }^{*}$ Corresponding author. croorganisms on the availability of the nutriments for the plants $[2,3]$.

In nitrificants bacteria, rhizospheric are developed ( $\mathrm{Ni}$ trobacter and Nitrosomonas); and denitrificants bacteria (Brasilense Azospirillum, Bacillus azotoformas, thiobacillus desnitrificans, Pseudomonas, etc.), those altogether play an important role inside of the cycle of the $\mathrm{N}$. The nitrificants bacteria they are of quimiotrofic metabolism and the oxidation of the $\mathrm{NH}_{4}^{+}$to $\mathrm{NO}_{2}^{-}$, it serves like power plant as these microorganisms whereas the $\mathrm{C}_{\text {org }}$ they obtain it from the fixation of the $\mathrm{CO}_{2}$, of the air or the atmosphere of the soil. The growth of these bacteria is smaller than the growth of the majority of the 
bacteria of the soil that are of quimiotrofic metabolism $[4,5]$.

Within the microorganisms, the bacteria constitute the only group that has the physiological characteristic to cause the denitrification. All the bacteria denitrificants are anaerobic, with the exception of the species of the sort Propionibacterium that fermenters anaerobic they are forced that is able to carry out the denitrification. Most of the denitrificants bacteria they are of quimiotrofic metabolism since they use carbohydrates, organic acids and diverse organic compounds like $\mathrm{C}$ and power plant during their anaerobic cycle in the presence of diverse oxides of $\mathrm{N}[6]$.

The activity, diversity and structure of these microorganisms are sensible to the changes in the edafic atmosphere caused by the carbon sources and energy, pressure, ventilation and interaction between the microorganisms, $\mathrm{pH}$, humidity, temperature, content of oxygen and nutriaments available [7]. The most important factor is the availability of nutriments because it promotes the activity of the microorganisms in the rhizosphere, measurement like rhizosphere phantom, which is of 2, 5 ground times greater fertilized than in grounds non fertilized; also microbiota measured with ${ }^{14} \mathrm{C}$ is tripled when fertilizers are applied.

\section{Materials and Methods}

This study was conducted in two phases. The first corresponded to establishing a greenhouse test for generating environments where microorganisms would study populations and the second consisted of determining the incidence microbial laboratory. A haplic vertisol from Guanajuato, Mexico was used [8]. The physical and chemical properties of the studied soil and water are shown in Tables 1 and 2. We used wheat (Triticum aestivum L.) variety "Tlaxcala F2000" classified as having an intermediate cycle and developed for natural rainfall conditions by the INIFAP (Instituto Nacional de Investigaciones Forestales, Agropecuarias y Pecuarias). This wheat has an average cycle of 118 days, with a harvesting interval from 107 to 135 days [9]. The applied fertilizers were: monoammonic phosphate plus urea termed a "commercial fertilizer" (CF), a vermicompost termed "organic fertilizer" (OF), and a slow release fertilizer (SRF) called "GAPU" (constituted by a clay matrix enriched with 8.1 and $6.3 \%$ of $\mathrm{N}$ and $\mathrm{P}$ in weight, respectively, in process to be patented). The treatments were designed to evaluate the simple effect of each one of these fertilizers and the combination of SRF plus OF. Vermicompost (containing $1.37 \%$ and $0.75 \%$ of $\mathrm{N}$ and $\mathrm{P}$, respectively) was produced with residues of plants used for gardening. Used waste and well waters came from urban zones from Montecillo, Texcoco, Mexico. The dose of fertilization of $\mathrm{N}$ and $\mathrm{P}$ used for the greenhouse
Table 1. Physical and chemical characteristics of the experimental soil.

\begin{tabular}{cccc}
\hline Variable & Method & Value & Units \\
\hline $\mathrm{N}$ & MicroKjeldahl & 0.07 & $\%$ \\
Extractable P & Olsen & 34 & $\mathrm{mg} \mathrm{kg}^{-1}$ \\
Organic matter & Walkley and Black & 1.4 & $\%$ \\
CCI & Extraction with & 39 & cmol $_{\mathrm{c}} \mathrm{kg}^{-1}$ \\
ammonium acetate & Potentiometer & 7.76 & \\
EH (relation 2:1) & Conductimeter & 0.69 & $\mathrm{dS} \mathrm{m}^{-1}$ \\
Sand & Bouyoucos & 10 & $\%$ \\
Lime & & 17 & $\%$ \\
Clay & & 73 & $\%$ \\
Textural class & & Clayish & \\
\hline
\end{tabular}

E.C. $=$ Electrical conductivity, $\mathrm{CCI}=$ Capacity of cationic interchange.

Table 2. Physical and chemical characteristics of the experimental water.

\begin{tabular}{cccc}
\hline Variable & Value & & Units \\
\hline Total N & Waste water & Well water & \\
$\mathrm{N}^{-\mathrm{NO}_{3}}$ & 72 & 32.00 & $\mathrm{mg} \mathrm{L}^{-1}$ \\
$\mathrm{~N}^{-\mathrm{NH}_{4}}$ & 6 & 22.27 & $\mathrm{meq} \mathrm{L}^{-1}$ \\
Soluble P-PO & 55 & 8.64 & $\mathrm{meq} \mathrm{L}^{-1}$ \\
Total P & 11 & 0.86 & $\mathrm{mg} \mathrm{L}^{-1}$ \\
pH & 39 & 0.60 & $\mathrm{mg} \mathrm{L}^{-1}$ \\
E.C. & 7.05 & 7.45 & \\
\hline
\end{tabular}

E.C. $=$ Electrical conductivity

experiment was greater than that recommended in the studied area in eastern Mexico "Bajío Guanajuatense" where the studied soil was collected. Following the recommendation of Terman, et al. (1962) [10] for greenhouse experiments, the dose was equivalent to 360 and $257 \mathrm{~kg}$ of $\mathrm{N}$ and $\mathrm{P}$ per ha, respectively. All N and P were applied at the time of sowing. The experimental units (EU) consisted of cylindrical pots which contained $2 \mathrm{~kg}$ of soil: without plants (designed to collect non rhizospheric soil) and with three plants (from which the rhizospheric soil was collected). The number of cylindrical pots was calculated so that in every date of sampling (55.67 and 97 days after sowing) three experimental units by treatment were collected (Table 3).

In order to obtain the rhizospheric soil, the soil portion used was that strongly adhered to the root. Ten grams were weighed separately of rhizospheric and non rhizo- 
Table 3. Treatments in the experiment.

\begin{tabular}{|c|c|c|c|c|}
\hline $\begin{array}{c}\text { Number } \\
\text { of } \\
\text { treatment }\end{array}$ & $\begin{array}{c}\text { Type } \\
\text { of } \\
\text { soil } \\
\end{array}$ & $\begin{array}{l}\text { Type of } \\
\text { fertilizer }\end{array}$ & $\begin{array}{l}\text { Type of } \\
\text { water }\end{array}$ & $\begin{array}{c}\text { Number } \\
\text { of } \\
\text { replicates }\end{array}$ \\
\hline 1 & RS & $\mathrm{CF}$ & Waste water & 3 \\
\hline 2 & RS & $\mathrm{CF}$ & Well water & 3 \\
\hline 3 & NR & $\mathrm{CF}$ & Waste water & 3 \\
\hline 4 & NR & $\mathrm{CF}$ & Well water & 3 \\
\hline 5 & RS & SRF & Waste water & 3 \\
\hline 6 & RS & SRF & Well water & 3 \\
\hline 7 & NR & SRF & Waste water & 3 \\
\hline 8 & NR & SRF & Well water & 3 \\
\hline 9 & RS & OF & Waste water & 3 \\
\hline 10 & RS & OF & Well water & 3 \\
\hline 11 & NR & OF & Waste water & 3 \\
\hline 12 & NR & OF & Well water & 3 \\
\hline 13 & RS & $\mathrm{SRF}+\mathrm{OF}$ & Waste water & 3 \\
\hline 14 & RS & $\mathrm{SRF}+\mathrm{OF}$ & Well water & 3 \\
\hline 15 & NR & $\mathrm{SRF}+\mathrm{OF}$ & Waste water & 3 \\
\hline 16 & NR & $\mathrm{SRF}+\mathrm{OF}$ & Well water & 3 \\
\hline 17 & RS & $\mathrm{C}$ & Waste water & 3 \\
\hline 18 & RS & $\mathrm{C}$ & Well water & 3 \\
\hline 19 & NR & $\mathrm{C}$ & Waste water & 3 \\
\hline 20 & NR & $\mathrm{C}$ & Well water & 3 \\
\hline $\begin{array}{l}\text { Total } \\
\text { units }\end{array}$ & $\begin{array}{c}\text { number } \\
\text { of }\end{array}$ & experimental & & 240 Unit \\
\hline
\end{tabular}

$\mathrm{SR}=$ Rhizospheric soil, $\mathrm{NR}=$ Non rhizospheric soil; $\mathrm{CF}=$ Commercial fertilizer, $\mathrm{SRF}=$ Slow release fertilizer, $\mathrm{OF}=$ Organic fertilizer (vermicompost), $\mathrm{C}=$ Control.

spheric soil. Each of these samples was added to $90 \mathrm{~mL}$ of Ringer solution. In the determination of the microbial incidence, the technique of the most probable number (MPN) was used for the quantification of nitrificant and denitrificant bacteria [11]. Selective growth media for the fractions of the rhizospheric and non rhizosphereic soil were used. A series of ten dilutions was used to inoculate five tubes with each level of dilution $\left(10^{-8}\right.$ to $\left.10^{-5}\right)$. The cultures were incubated to $28^{\circ} \mathrm{C}$ during 7 and 21 days for the denitrificant and nitrificant bacteria, respectively and their presence was identified by using specific diagnostic tests. $\left(\mathrm{CaCO}_{3}\right) \mathrm{NH}_{4}$ was used for Nitrosomonas, $\left(\mathrm{CaCO}_{3}\right)$ $\mathrm{NO}_{2}$ for Nitrobacter and of Griess-Ilosvay reagent for both groups [12].

\section{Results}

The experimental design did not allow statistical eva- luation of sampling interaction with the other factors evaluated: type of water, fertilizers and soil type (vs. rhizosphere. Rhizospheric not) for any of the populations of bacteria quantified. Figure 1 shows the temporal changes of the populations of denitrificant bacteria of non rhizospheric soil in relation to plant age with waste water and well water. In general terms, there was an increase in denitrificant bacteria populations, when the plan age increased, indepently of type of water. The average effect of the types of water, soil and fertilizers (as well as their interactions between them) was not significant $(p>0.05)$ on the development of the denitrificant bacteria populations, evaluated MPN. In general terms, The populations denitrificant were higher in non rhizospheric in relation to those found in rhizospheric soil, independently of the type de water. In average, denitrificant from non rhizospheric soil populations were higher in well water than in waste water. Mean while, the opposite trend was observed in rhizospheric soil (Table 4).

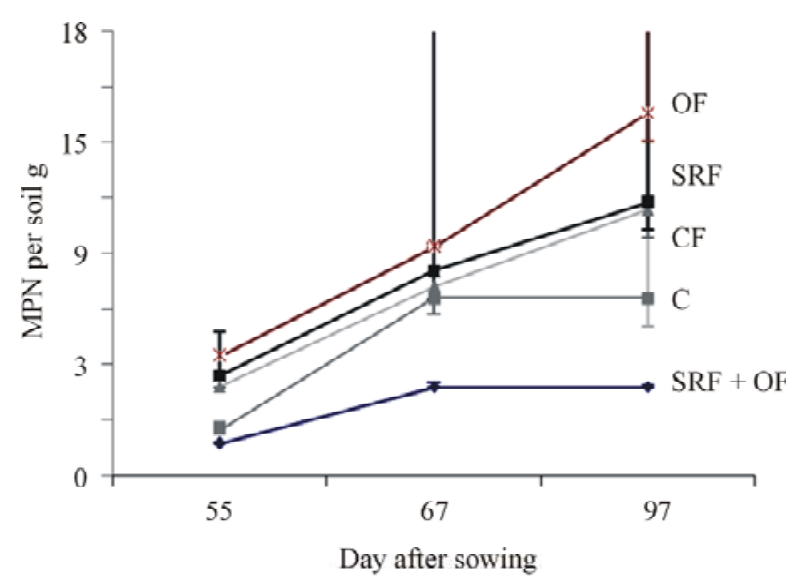

(a)

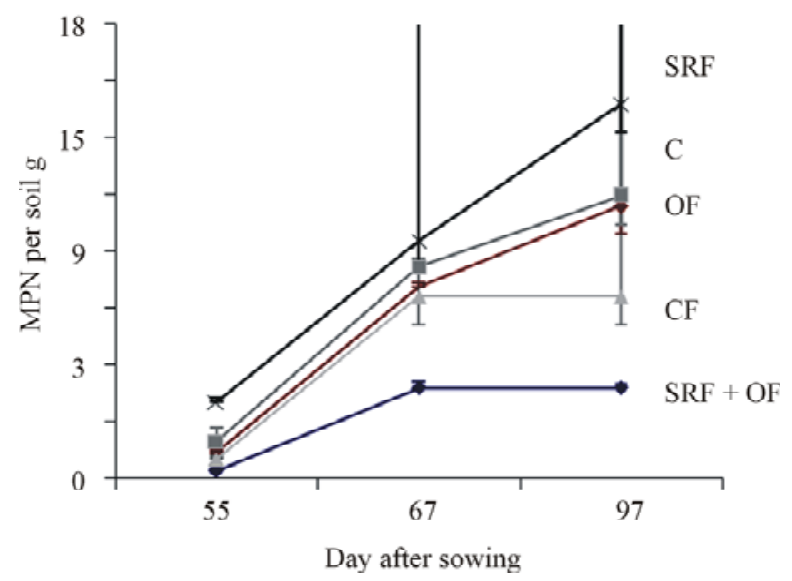

(b)

Figure 1. MPN of denitrificant bacteria in non-rhizospheric soil irrigated with (a) waste water or (b) well water. CF = Commercial fertilizer, SRF $=$ Slow release fertilizer, $\mathrm{OF}=$ Organic fertilizer (vermicompost), $\mathrm{C}=$ Control. Vertical lines show $95 \%$ confidence intervals. 
In relation to fertilizers, the highest populations of denitrificant bacteria were observed in Fertilizer slow release and the lowest ones were recorded in Commercial Fertilizer (Table 5).

Pointed out that plant organic compounds can be used as a source of nutrients energy to desnitrificants bacteria. Also it is inferred, that the waste water can contain in its $\mathrm{M}$. O factors of growth for same the bacteria; nevertheless the toxic elements can predominate in their negative effect that limits the increase of the bacterial population [13]. It was observed (Table 5) that when SRF was applied there is minor proliferation of denitrificants bacteria, compared with the witness and the application of other fertilizers (OF and $\mathrm{CF}$ ) and his combinations. This can indicate that the $\mathrm{N}$ of the SRF is less susceptible to lose itself by denitrification.

Figure 2 shows the temporal changes of the populations of Nitrobacter bacteria of non rhizospheric soil in relation to plant age with waste water and well water. In general terms, there was an increase in denitrificant bacteria populations, when the plan age increased, indepently of type of water.

The average effect of the types of water, soil and fertilizers (as well as their interactions between them) was not significant $(\mathrm{p}>0.05)$ on the development of the $\mathrm{Ni}$ trobacter bacteria populations, evaluated MPN. In general terms, the populations Nitrobacter were higher in non rhizospheric in relation to those found in rhizo-

Table 4. Average of MPN of denitrificant bacteria in two types of water and soil during three samplings.

\begin{tabular}{cccc}
\hline Type of water & $\begin{array}{c}\text { Rhizospheric } \\
\text { soil }\end{array}$ & $\begin{array}{c}\text { Non rhizospheric } \\
\text { soil }\end{array}$ & Average \\
\hline Waste water & $0.65 \times 10^{5}$ & $0.82 \times 10^{5}$ & $0.73 \times 10^{5}$ \\
Well water & $0.26 \times 10^{5}$ & $7.3 \times 10^{5}$ & $3.7 \times 10^{5}$ \\
Average & $0.45 \times 10^{5}$ & $4.1 \times 10^{5}$ & \\
\hline
\end{tabular}

Table 5. Average of the MPN of denitrificant bacteria in rhizospheric soil and non rhizospheric soil with addition of three types of fertilizer.

\begin{tabular}{cccc}
\hline Fertilizer & Rhizospheric soil & $\begin{array}{c}\text { Non rhizospheric } \\
\text { soil }\end{array}$ & Average \\
\hline CF & $6.5 \times 10^{5}$ & $8.3 \times 10^{5}$ & $7.4 \times 10^{5}$ \\
C & $5.4 \times 10^{5}$ & $6.4 \times 10^{5}$ & $5.9 \times 10^{5}$ \\
OF & $0.31 \times 10^{5}$ & $0.83 \times 10^{5}$ & $0.57 \times 10^{5}$ \\
SRF + OF & $0.27 \times 10^{5}$ & $0.37 \times 10^{5}$ & $0.32 \times 10^{5}$ \\
SRF & $0.11 \times 10^{5}$ & $0.11 \times 10^{5}$ & $0.11 \times 10^{5}$ \\
Average & $2.52 \times 10^{5}$ & $3.2 \times 10^{5}$ & \\
\hline
\end{tabular}

$\mathrm{CF}=$ Commercial fertilizer, $\mathrm{SRF}=$ Slow release fertilizer, $\mathrm{OF}=$ Organic fertilizer (vermicompost), $\mathrm{C}=$ Control.

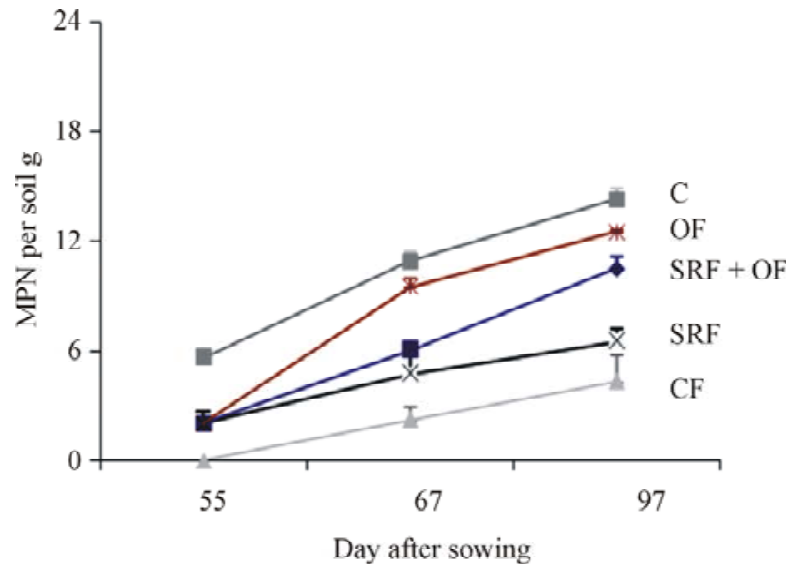

(a)

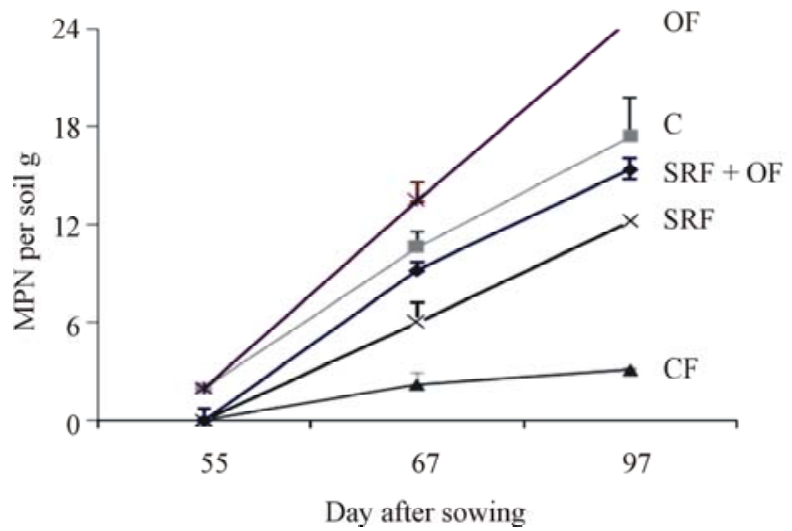

(b)

Figure 2. MPN of Nitrobacter in non-rhizospheric soil irrigated with (a) waste water or (b) well water. CF = Commercial fertilizer, SRF $=$ Slow release fertilizer, $\mathrm{OF}=\mathrm{Or}-$ ganic fertilizer (vermicompost), $\mathrm{C}=$ Control. Vertical lines show $95 \%$ confidence intervals.

spheric soil, independently of the type de water. In average, Nitrobacter from non rhizospheric soil populations were higher in well water than in waste water. Mean while, the opposite trend was observed in rhizospheric soil (Table 6).

In relation to fertilizers, the highest populations of $\mathrm{Ni}$ trobacter bacteria were observed in Fertilizer slow release and the lowest ones were recorded in Commercial Fertilizer (Table 7). Figure 3 shows the temporal changes of the Nitrosomonas populations of bacteria of non rhizospheric soil in relation to plant age with waste water and well water. In general terms, there was an increase in Nitrosomonas bacteria populations, when the plan age increased, indepently of type of water (Table 8).

In Table 9, it was observed that the fertilizers that promote the MNP of Nitrobacter are the SRF and the CF. The most probable number of the denitrificants bacteria is greater than in Nitrobacter and Nitrosomonas as it indicates [14] that indicates for example the root of wheat has a strong effect on the microbial populations within 
Table 6. Average of MPN of Nitrobacter in two types of water and soil during three samplings.

\begin{tabular}{cccc}
\hline Type of water & $\begin{array}{c}\text { Rhizospheric } \\
\text { soil }\end{array}$ & $\begin{array}{c}\text { Non rhizospheric } \\
\text { soil }\end{array}$ & Average \\
\hline Waste water & $7.2 \times 10^{5}$ & $10 \times 10^{5}$ & $8.6 \times 10^{5}$ \\
Well water & $3.5 \times 10^{5}$ & $2.6 \times 10^{5}$ & $3.1 \times 10^{5}$ \\
Average & $5.3 \times 10^{5}$ & $6.3 \times 10^{5}$ & \\
\hline
\end{tabular}

Table 7. Average of the MPN of Nitrobacter in rhizospheric soil and non rhizospheric soil with addition of three types of fertilizer.

\begin{tabular}{cccc}
\hline Fertilizer & $\begin{array}{c}\text { Rhizospheric } \\
\text { soil }\end{array}$ & $\begin{array}{c}\text { Non rhizospheric } \\
\text { soil }\end{array}$ & Average \\
\hline CF & $12 \times 10^{5}$ & $1.3 \times 10^{5}$ & $6.7 \times 10^{5}$ \\
C & $9.2 \times 10^{5}$ & $6.3 \times 10^{5}$ & $7.7 \times 10^{5}$ \\
SRF & $1.9 \times 10^{5}$ & $0.9 \times 10^{5}$ & $1.4 \times 10^{5}$ \\
SRF + OF & $1.9 \times 10^{5}$ & $5.2 \times 10^{5}$ & $3.5 \times 10^{5}$ \\
OF & $1.1 \times 10^{5}$ & $6.4 \times 10^{5}$ & $3.7 \times 10^{5}$ \\
Average & $5.2 \times 10^{5}$ & $4.0 \times 10^{5}$ & \\
\hline
\end{tabular}

$\mathrm{CF}=$ Commercial fertilizer, $\mathrm{SRF}=$ Slow release fertilizer, $\mathrm{OF}=$ Organic fertilizer (vermicompost), $\mathrm{C}=$ Control.

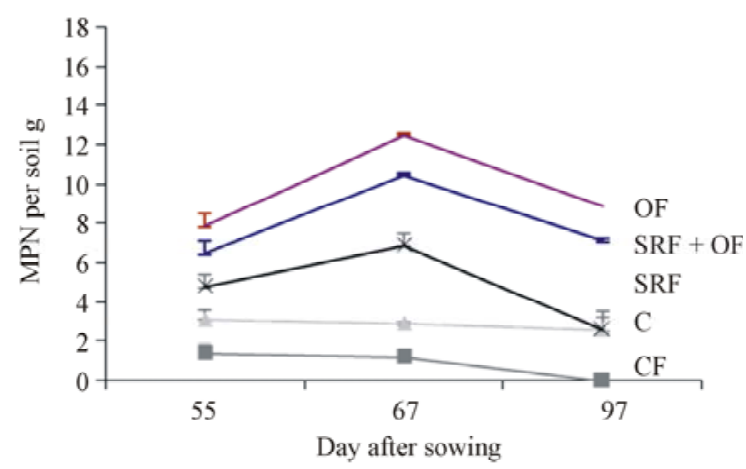

(a)

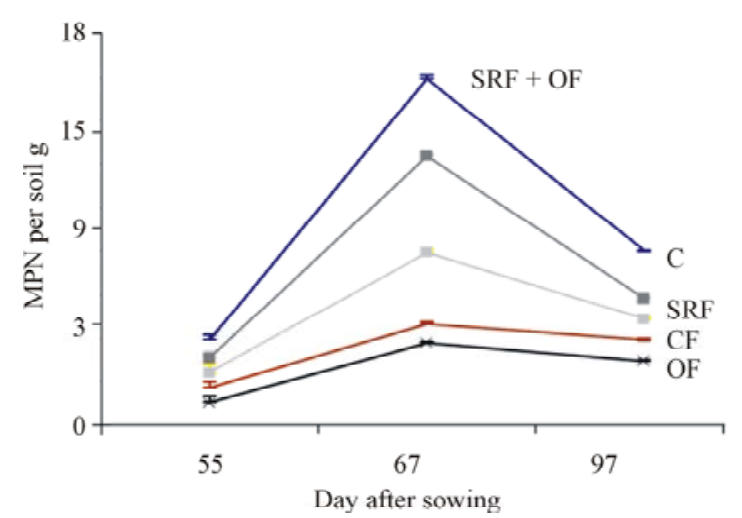

(b)

Figure 3. MPN of Nitrosomonas in non- rhizospheric soil irrigated with (a) waste water or (b) well water. CF = Commercial fertilizer, SRF $=$ Slow release fertilizer, $\mathrm{OF}=$ Organic fertilizer (vermicompost), $\mathrm{C}=$ Control. Vertical lines show $95 \%$ confidence intervals. which denitrificant emphasizes the high number of bacteria.

\section{Discussion}

In this experiment, we possibly suppose that there was no an independently marked rhizospheric effect of the type of fertilizer and used water, had to that the sampled rhizospheric zone was not the adapted one, due to the space so reduced in that were the wheat plants. However, the MNP of the bacteria studied in this work was not affected by the zone by the roots nor by the fertilization with $\mathrm{N}$ as it concludes $[1,2,15]$; which they investigated that the composition of the community of bacteria in the rhizosphere is affected by the complex interaction between the type of soil, species of plants location of the zone by the roots and the nitrogen fertilization. Apparently, there was no a marked rhizospheric effect on $\mathrm{Ni}$ trosomonas (Table 9), because the existing potential in this zone to carry out the liberation of the $\mathrm{NH}_{4}^{+}$, constitutes necessary the power provision for the development of this sort of nitrificants bacteria [16]. Contrary to the referred thing by [17] on the inhibiting effect caused by the organic compound presence on the development of the nitrificantes populations, it was verified in the present investigation that in the rhizosphere, in which a great abundance of organic compounds exists, these populations were stimulated (Tables 6 and 7), which agrees with the results obtained by [18], for the rhizosphere of

Table 8. Average of MPN of Nitrosomonas in two types of water and soil during three samplings.

\begin{tabular}{cccc}
\hline Type of water & $\begin{array}{c}\text { Rhizospheric } \\
\text { soil }\end{array}$ & $\begin{array}{c}\text { Non rhizospheric } \\
\text { soil }\end{array}$ & Average \\
\hline Well water & $6.1 \times 10^{5}$ & $3.1 \times 10^{5}$ & $4.6 \times 10^{5}$ \\
Waste water & $2.2 \times 10^{5}$ & $2.3 \times 10^{5}$ & $2.3 \times 10^{5}$ \\
Average & $4.1 \times 10^{5}$ & $2.7 \times 10^{5}$ & \\
\hline
\end{tabular}

Table 9. Average of the MPN of Nitrosomonas in rhizospheric soil and non rhizospheric soil with addition of three types of fertilizer.

\begin{tabular}{cccc}
\hline Fertilizar & $\begin{array}{c}\text { Rhizospheric } \\
\text { soil }\end{array}$ & $\begin{array}{c}\text { Non rhizospheric } \\
\text { soil }\end{array}$ & Average \\
\hline CF & $9.3 \times 10^{5}$ & $3.0 \times 10^{5}$ & $6.2 \times 10^{5}$ \\
C & $4.8 \times 10^{5}$ & $4.1 \times 10^{5}$ & $4.5 \times 10^{5}$ \\
OF & $3.1 \times 10^{5}$ & $2.2 \times 10^{5}$ & $2.7 \times 10^{5}$ \\
SRF + OF & $2.1 \times 10^{5}$ & $2.8 \times 10^{5}$ & $2.5 \times 10^{5}$ \\
SRF & $1.6 \times 10^{5}$ & $1.7 \times 10^{5}$ & $1.7 \times 10^{5}$ \\
Average & $4.2 \times 10^{5}$ & $2.8 \times 10^{5}$ & \\
\hline
\end{tabular}

$\mathrm{CF}=$ Commercial fertilizer, $\mathrm{SRF}=$ Slow release fertilizer, $\mathrm{OF}=$ Organic fertilizer (vermicompost), $\mathrm{C}=$ Control. 
some plants. However, the magnitude of the development shown by the nitrificants bacteria in the rhizosphere of wheat, and with its development in the fraction of the rhizospheric soil (Figure 2), it suggests in her takes place an effective process of nitrification [19]. Woldendorp and Laanbroek (1989) [20] reported that the rate of nitrification is a predominant process in the rhizosphere, which can lead to a considerable production of $\mathrm{NO}_{3}^{-}$in this zone. However, it was difficult to make a real estimation of the rate from production of $\mathrm{NO}_{2}^{-}$in the rhizosphere, which can lead to a considerable production of $\mathrm{NO}_{3}^{-}$in that zone, since in her great part of the $\mathrm{N}$ available is directed towards immobilization and the absorption by the roots. The denitrificants bacteria also were stimulated in greater number of cells as much in the rhizosphere of the ground as in the non rhizospheric soil the population increase can be in favor certain not only of the great present availability of composed of carbon; but also by the exudate production in the rhizosphere, which can lead to a considerable production of $\mathrm{NO}_{3}^{-}$on the part of the nitrificants bacteria, since he himself ion is used by the denitrificants bacteria like electron acceptor before the reduced present oxygen concentration in the rhizosphere [21]. The number of cells or MNP was obtained in Nitrobacter and Nitrosomonas was greater to which this is reported generally can be viable since although the conditions in which work was of anaerobiosis the sort of the Nitrobacter can grow occasionally under anaerobic atmosphere breathing where the M. O. is mineralized $[4,22,23]$. Kowalchuk and Stephen, (2001) [4], emphasized that when the technique of the MNP is used the value of the Nitrosomonas underestimates low values of the real number of cells caused by factors as $\mathrm{pH}$ and the provision of N. Also, Watson [24] reported that the count of Nitrobacter is influenced by $\mathrm{pH}$. Although in our case we discarded that $\mathrm{pH}$ has been the factor that I influence in the number of cells that we reported for these sorts. We agree with reported by Rice and Pancholy [25] who emphasize that the MNP can be a questionable procedure of count, this is important if they are possible to be seen that they exist alternative in the interpretation of the changes of $\mathrm{NH}_{4}^{+}$and $\mathrm{NO}_{3}^{-}$in the soil. The low concentrations of $\mathrm{NO}_{3}^{-}$can be the result of the best efficiency in the conduction of these and the increase of the $\mathrm{NH}_{4}^{+}$can be due to the increase of $\mathrm{N}$ in the soil. A low concentration of $\mathrm{NO}_{3}^{-}$can as resulting from happen in an actively nitrificant habitat the denitrification or by the fast conduction towards the plants as it indicates Allison and Prosser [26]. On the other hand, also it can be that the efficiency of the method of the MNP low is compared with other methods possibly this must to the selectivity of means of used growth and to the presence of added cells to the dissolutions as they indicate [27]. However, the MNP of Nitrobacter and
Nitrosomonas of these sorts suggest both processes

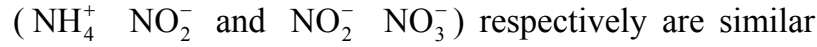
so that both steps produce different amounts from energy. From the uncertainty of the method of the MNP diverse mechanisms exist that can explain this:

1) Nitrosomonas it has a greater mortality than the $\mathrm{Ni}$ trobacter. This happens particularly in soils where this sort (Nitrosomonas) is died by the acid production [27, 28].

2) Heterotrofic development of Nitrobacter species [29].

3) Anaerobic growth of Nitrobacter through $\mathrm{NO}_{3}^{-}$ and organic substrat [30].

4) Denitrificants relation $\mathrm{NO}_{2}^{-} / \mathrm{NO}_{3}^{-}$between Nitrobacter and bacteria [31].

\section{Conclusions}

1) The effects of the types of water, fertilizer and ground the MNP of denitrificants bacteria and those affected in form differential that take part in the transformation of $\mathrm{NH}_{4}^{+}$to $\mathrm{NO}_{3}^{-}$(Nitrobacter and Nitrosomonas).

2) The MNP of the denitrificants bacteria was not affected by the types of fertilizer, soil and water of irriga tion.

3) The MNP of Nitrobacter was promoted positively by the type of soil and fertilizer in average. Nitrobacter was developed better in the non rhizospheric soil. This sort of bacteria was stimulated by the OF and the combination of SRF + OF. The waste water did not have an effect in the MNP of this group of bacteria compared with the well water.

4) The MNP of Nitrosomonas. It was affected only by the type of soil. This sort of bacteria have better development in the rhizospheric soil.

\section{Acknowledgments}

This study was financed by project CONACYT 38999 .

\section{REFERENCES}

[1] J. M. Lynch, "Resilience of the Rhizosphere Anthropogenic Disturbance,” Biodegradation, Vol. 13, No. 1, 2002, pp. 21-27. doi:10.1023/A:1016333714505

[2] P. Marschner, C.-H. Yang, R. Lieberei and D. E. Crowley, "Soil and Plant Effects on Bacterial Community Composition in the Rizosphere," Soil Biology and Biochemistry, Vol. 33, No. 11, 2001, pp. 1437-1445. doi:10.1016/S0038-0717(01)00052-9

[3] C.-H. Yang and D. E. Crowley, "Rhizosphere Microbial Community Structure in Relation to Root Location and Plant Iron Nutritional Status," Applied and Environmental Microbiology, Vol. 66, No. 1, 2000, pp. 345-351. doi:10.1128/AEM.66.1.345-351.2000

[4] G. A. Kowalchuk and R. J. Stephen, "Ammonia-Oxiding 
Bacteria: A Model for Molecular Microbiology Ecology," Annual Review of Microbiology, Vol. 55, 2001, pp. 485-529. doi:10.1146/annurev.micro.55.1.485

[5] P. Kent, and J. Triplett, "Microbial Communities and Their Interactions in Soil and Rhizosphere Ecosystems," Annual Review of Microbiology, Vol. 56, 2002, pp. 222-236. doi:10.1146/annurev.micro.56.012302.161120

[6] W. De Boer and Y. G. A. Kowalchuk, "Nitrification in Acid Soils: Micro-Organims and Mechanisms," Soil Biology and Biochemistry, Vol. 33, No. 7-8, 2001, pp. 853866. doi:10.1016/S0038-0717(00)00247-9

[7] A. G. O'Donell, M. Seasman, A. Macrae, I. Waite and J. T. Davies, "Plants and Fertilazers as Drivers of Change in Microbial Community Structure and Function in Soil," Plant and Soil, Vol. 232, No. 1-2, 2001, pp. 135-145. doi:10.1023/A:1010394221729

[8] INEGI (Instituto Nacional de Estadística, Geografía e Informática), "Síntesis de Información Geográfica de Guanajuato," Carta Estatal de Suelos, Anexo Cartográfico, México, 2001a.

[9] M. Villaseñor, E. Espitia, J. Huerta, A. María, L. Osorio and A. Aguirre, "Tlaxcala F2000: Nueva Variedad de Trigo Para Siembras de Temporal en México," SAGAR, INIFAP, CIRCE, Campo Experimental Valle de México, Folleto Técnico N., Chapingo, Estado de México, México, Vol. 1, 2000, p. 20.

[10] G. L. Terman, D. R. Boulding and J. R. Webb. "Evaluation of Fertilizers by Biological Methods," Advances in Agronomy, Vol. 14, 1962, pp. 265-319. doi:10.1016/S0065-2113(08)60440-X

[11] H. J. Benson, "Microbiological Applications," Brown Company Publishers, Dubuque, 1981, p. 450.

[12] C. A. Black, D. O. Evans, I. L. White, L. E Ensminger and F. E. Clark, "Methods of Soil Analysis. II. Chemical and Microbiological Properties," American Society of Agronomy, Madison, 1965, pp. 1788.

[13] G. Oron, C. Campos, L. Guillerman and M. Salgot, "Wastewater Treatment, Renovation and Reuse for Agricultural Irrigation in Small Communities," Agricultural Water Management, Vol. 38, No. 3, 1999, pp. 223-234. doi:10.1016/S0378-3774(98)00066-3

[14] C. R. Ferrera, "Efecto de la rizosfera," In: C. R. Ferrera and J. M. Pérez, Eds., Agromicrobiología, Colegio de Postgraduados, Campeche, 1995, pp. 36-53.

[15] P. Marschner, J. Gerendás and B. Sattelmacher, "Effect of N Concentration and N Source on Root Colonitation by Pseudomonas Fluorescens 2-79 RLl," Plant Soil, Vol. 215, No. 2, 1999, pp. 135-141. doi:10.1023/A:1004373007606

[16] L. W. Belser, "Population Ecology of Nitrifying Bacteria," Annual Review of Microbiology, Vol. 3, 1979, pp. 309-333. doi:10.1146/annurev.mi.33.100179.001521

[17] J. H. G. Slangen and P. Kerkhoff, "Nitrification Inhibitors in Agriculture and Horticulture: A Literature Review," Fertilizer Research, Vol. 5, No. 1, 1984, pp. 1-76. doi:10.1007/BF01049492

[18] H. K. Russell and L. N. Nelson, "Interactions among
Nitrogen-Transforming Bacteria and Nitrogen-Fixing Pisum sativum L. in Laboratory Sand Columns," Plant Soil, Vol. 122, No. 2, 1990, pp. 157-167. doi:10.1007/BF02851970

[19] P. Berg and T. Rosswall, "Seasonal Variations in Abundance and Activity of Nitrifiers in Four Arable Cropping Systems," Microbial Ecology, Vol. 13, No. 1, 1987, pp. 75-87. doi:10.1007/BF02014964

[20] J. W. Woldendorp and H. J. Laandroek, "Activity of Nitrifiers in Relation to Nitrogen Nutrition of Plants in Natural Ecosystem," Plant Soil, Vol. 115, No. 2, 1989, pp. 217-228. doi:10.1007/BF02202590

[21] R. Y. Stanier, E. A. Adelberg and J. L. Ingraham, "Microbiología," Reverte, Barcelona, España. 1984. pp. 836.

[22] G. J. Holt, R. N. Krieg, P. H. Sneath, J. T. Staley and S. T. Williams, "Bergey Manual of Determinative Bacterialogy," Williams \& Wilkins, Baltimore Maryland, 1994, pp. 448-453.

[23] W. De Boer, P. J. A. Klein Gunnewiek and D. Parkinson, "Variability of N Mineralization and Nitrification in a Simple, Simulated Microbial Forest Soil Community," Soil Biology \& Biochemistry, Vol. 28, No. 2, 1996, pp. 203-211. doi:10.1016/0038-0717(95)00124-7

[24] S. W. Watson, "MNP Tecnique for Population Nitrifier," In Syst. Bacterial, Vol. 21, 1971, pp. 254-270.

[25] E. L. Rice and S. K. Pancholy, "Methods for Estimating Nitrifier Populations Inhibition of Nitrification by Climax Ecosystems," American Journal of Botany, Vol. 60, No. 7, 1973, pp. 691-702. doi:10.2307/2441448

[26] S. M. Allison and J. I. Prosser, "Ammonia Oxidation at Low by Attached Populations of Nitrifying Bacteria," Soil Biology \& Biochemistry, Vol. 25, No. 7, 1993, pp. 935-941. doi:10.1016/0038-0717(93)90096-T

[27] W. De Boer, P. J. A. Klein Gunnewiek and H. J. Laanbroek, "Ammonium-Oxidation at Low $\mathrm{pH}$ by a Chemolithotrophic Bacterium Belonging to the Genus Nitrospira," Soil Biology \& Biochemistry, Vol. 27, No. 2, 1995, pp. 127-132. doi:10.1016/0038-0717(94)00157-V

[28] L. Klemedtsson, Q. Q. Jiang, A. K. Klemedtson and L. R. Bakken, "Autotrophic Ammonium-Oxidising Bacteria in SWEDISH Mor Humus," Soil Biology and Biochemistry, Vol. 31, No. 6, 1999, pp. 839-847. doi:10.1016/S0038-0717(98)00183-7

[29] W. De Boer, P. J. A. Klein Gunnewiek, M. Veehuis, E. Bock and H. J. Laanbroek, "Nitrification at Low pH by Aggregated Chemolithotrophic Bacteria," Applied and Environmental Microbiology, Vol. 57, No. 12, 1991, pp. 3600-3604.

[30] A. Teske, E. Elm, J. M. Regan, S. Toze, B. E. Rittmann and D. A. Stahl, "Evolutionary Relationships among Ammonia- and Nitrite-Oxidizing Bacteria," Journal of Bacteriology, Vol. 176, No. 21, 1994, pp. 6623-6630.

[31] J. G. Kuenen and L. A. Robertson, "Combined Nitrification-Denitrification Processes," FEMS Microbiology Reviews, Vol. 15, No. 2-3, 1994, pp. 109-117. doi:10.1111/j.1574-6976.1994.tb00129.x 